\title{
Economic Issues in 1974
}

\author{
Remarks by DARRYL R. FRANCIS, President, Federal Reserve Bank of St. Louis, \\ Before The National Association of Investment Clubs, \\ St. Louis, Missouri, October 19, 1973
}

T IS GOOD to have this opportunity to discuss with you some of my views on the outlook for the United States economy in the near future. It happens that we presently stand in one of those rare situations in which there is a wide divergence of forecasts with regard to almost all areas of economic interest. Moreover, economic issues, for various reasons, have become more newsworthy and of greater interest to the average citizen in recent times.

Let me first summarize briefly the current economic situation and then address myself to four broad questions:

1) When will inflation end?

2) Will there be a recession?

3) Will there be a credit crunch?

4) What is the ontlook for the international monetary situation?

I must tell you now that I will advance neither specific numerical forecasts nor quick and easy solutions to our existing economic problems. The adoption of specific and usually optimistic targets, and the employment of quick, politically expedient solutions in an attempt to achieve them, have, in my opinion, contributed much to our current economic difficulties.

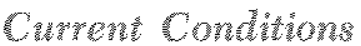

The present time is relatively prosperous, and therefore should be an enjoyable one for most people - not only with regard to economic well being, but in other important respects. The unemployment rate is lower than it has been in several years, corporate profits after taxes are almost double their 1970 low point, per capita disposable personal income has never been greater, and even lost output due to labor strikes was at a nine-year low in the first half of 1973. Also, this country's participation in the bitterly divisive Vietnam conflict has ended, no more young people are being drafted, and social unrest has declined significantly.

However, a number of factors suggest we are not enjoying our prosperity to the degree one might expect. The stock market, often taken to reflect the public's mood, has been depressed throughout most of 1973. A new measure of welfare has been advo cated by Professor Paul Samuelson which is obtained, in part, by eliminating ostensibly undesirable goods, such as pollution and military expenditures, from total output. This index has been growing progressively slower relative to gross national product in recent years, indicating our happiness has not kept pace with our GNP.

The index of consumer sentiment, which is compiled on the basis of answers to questions such as "will you be better off financially a year from now" and "will the country have good times or bad over the next five years," was about as low in the second quarter of 1973 as in the depths of the 1970 recession, and lower than at any point in the period from 1957 to 1969 .

Now, I have no great confidence in any of these kinds of indexes, singly or even en masse, because attitudes and welfare are so difficult to measure. But I do happen to agree that there currently exist serious economic and noneconomic problems which are contributing to a widespread feeling of malaise, or general unhappiness. 
Much of this atmosphere can be traced to the failure of policymakers to inform the public of the hard choices which must be made in a world where resources are limited and desires are not. It is my belief that by fostering the impression that there are no problems which cannot be cured by government action, policymakers have unnecessarily elevated the public's expectations and then dashed their hopes when confronted with economic reality. Let me give you some examples.

In the mid-1960s, the Federal Government greatly expanded both its domestic outlays, primarily for the Great Society Programs, and its foreign involvement, mainly in the form of defense expenditures for the Vietnam conflict. After several years and numerous glowing reports on both projects, it appears to me that the main effect on the domestic economy of the expenditure of many billions of dollars has been severe inflationary pressures. The attempt to maintain both a "guns and butter" economy has satisfed few and disappointed many.

Just a few years ago, cleaning up the environment became a major objective of public policy, with little thought as to the effects of single-minded pursuit of such an admirable goal on our energy reserves. Now that we have found that our energy resources are more limited than we thought, environmental concerns are battling crash energy programs for newspaper headlines. Thus, it is my contention that the public has discovered the hard choices to be made only after having been allowed to believe the environmental objective could be attained with minor costs over a relatively short span of time.

Some time ago, the public was told that the adoption of wage and price controls was a temporary expedient to relieve inflationary pressures in a less than fully employed economy. The controls were to be removed before shortages and economic uncertainty, two by-products of price controls in a high employment economy, would appear. The "temporary" controls are now into their fourth phase. In the current high-employment economy, shortages and economic uncertainty have emerged along with the inflationary pressures that the controls were adopted to alleviate.

There are many other cases in which the well-meaning efforts of policymakers to achieve objectives in one area have caused undesirable side effects in another. State usury laws, intended to prohibit the financial exploitation of small borrowers, have deprived such borrowers of virtually any access to credit in tight money periods. Minimum wage laws were adopted to insure a minimum level of income to everyone. However, many studies indicate that the main effect has been higher wages for workers already holding comfortable jobs and unemployment for many of the low-income workers the law was supposed to benefit. Government inducements to foreigners to buy our products, and thereby improve our balance-ofpayments position, were recently reversed in order to stem complaints about foreigners buying up our scarce goods.

Attempts by the monetary authorities to moderate the tendency of interest rates to rise in the face of strong credit demand have resulted in sharp increases in the money stock and, subsequently, intensified inflationary pressures and even higher interest rates. The extended freeze on beef prices was, of course, not designed to dry up beef supplies or stimulate cattle rustling, but that was its effect. The current restrictions on domestic fertilizer prices at levels considerably below world market prices, if not relieved, could result in the marketing by U.S. farmers of smaller crops in the near future than would otherwise have been the case, despite the release of more land for crop production.

The list of well-intentioned efforts in pursuit of worthy social and economic objectives has become very long. The fact that many of our current problems are directly attributable to such efforts has not discouraged the majority of policymakers from trying. Anyone with a knowledge of a few economic principles relating to basic supply and demand forces could have predicted the adverse side effects which fol lowed many of the earlier policy actions.

Unfortunately, predicting the policy actions themselves is much more difficult. The increased size of government, and stepped-up governmental intervention in market forces, has made it more necessary than ever before to recognize the influence of government actions on economic projections. What will happen in the remainder of 1973 has been largely determined by earlier policy actions, but much of economic developments in 1974 and beyond depend on policy actions yet to occur.

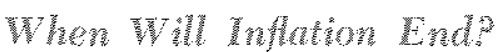

Recent polls have shown that the issue which Americans are most concemed about today is inflation. The fact that the current inflation has persisted longer than any in the post-World War II period may partially explain the current malaise. The public is 
quite cognizant that rising prices are eroding their incomes and their savings, while depreciating the value of the dollar internationally. It is not surprising that they are worried about what inflation will do to their futures. It is an issue that directly strikes every citizen, unlike war, unemployment, or even Watergate.

It is rather disconcerting to learn from some public opinion polls that the average citizen has little or no idea of the cause (and by implication - the cure) of inflation. Large corporations, unions, or some sinister "middlemen" are typically blamed, Rarely are fiscal or monetary actions thought to be the basic cause of inflation.

The common sense answer to the inflation question, which one hears surprisingly few times outside economic circles, is "too much money chasing too few goods." The volume of goods and services produced over a long period depends mostly on the size of the population that is of working force age, their degree of education, the extent of technological development, and the quantity and quality of raw resources and capital. The quantity of money produced which chases the goods is determined primarily by the monetary authorities, and this quantity could be closely controlled.

Thus, technically, it is not a difficult matter to eliminate inflation by reducing the rate of growth in the volume of money that is chasing the goods and services. Unfortunately, historical evidence indicates that the initial consequence of a marked and sustained reduction in the rate of growth of the money supply has been a temporary slowing in the rate of growth of real output and a rise in the unemployment rate. A lessening of price pressures normally has not occurred for an extended period after adoption of the restrictive policy. This is because the public, after repeated bouts with inflation, simply has not believed that policymakers would stick with the restrictive action long enough to make it work.

Public opinion and attitudes are important not only with regard to determining the length of time it takes to get inflation under control, but they also influence the tools employed in the battle. Even after price rises had begun to slow in 1970 and 1971 as a result of the restrictive stabilization policies undertaken in 1969, progress was not fast enough to satisfy the public nor their elected representatives. Polls taken in mid-1971 indicated that many people thought direct controls should be used to slow the inflationary spiral. Controls appeared to be a costless way of curbing price rises, by getting at the "sinister" middleman, with no ill effects to befall law-abiding citizens and firms. Controls had the appearance of working for awhile when there was little excess demand in the country. Once the economy approached full capacity utilization, as it did over the past year, it became clear that controls not only were unable to stop inflation, but could cause serious shortages, black markets, and confusion.

Now, after controls have been tried, and despite the problems of lloods, bad weather, and poor Russian and Chinese harvests, the basic, underlying cause of inflation remains - too much money chasing too few goods. In fact this has been the problem world-wide, as money supplies throughout the world have pushed up domestic prices.

Money supply growth in England, Japan, Germany, France, and Canada, to name a few countries, has virtually exploded during the past two or three years. In the United States, money supply growth moved up from about a 2 or 3 percent rate in the 1950s and early 1960 s, to a 6 percent average rate over the past five years. The result has been inflation, high interest rates, and dollar devaluation.

The cure for inflation has not changed, despite the freezing, semi-freezing and unfreezing of prices. The reversal of stimulative monetary and fiscal actions is a prerequisite to the reduction of inflationary pressures. Because of the lag of price changes behind changes in the rate of growth of the money stock, it probably would be not only months, but several years before the adoption of moderate policy actions would have any lasting, observable effect on the inflation rate. A severely restrictive policy could accomplish the job faster, but the cost in terms of lower employment and output would be more than most of us are prepared to pay.

And I hasten to add that the use of pervasive wageprice controls in the current high employment economy would not serve to speed up the end of inflation. At best, controls have only some minor, distorting effect on the timing of individual price changes, but no lasting effect on the general inflation rate. Experience both here and abroad has shown that adoption of a price freeze under the current circumstances only delays the rise in prices. You can't stop inflation by passing a law against it any more than you can stop unemployment by passing a law against that.

Since it is my view that there is no easy, costless way to end inflation through controls, it appears to me that moderate stabilization actions which avoid the stop-go excesses of the past would be appropriate. 
Even this course of action could not be undertaken now without some cost in terms of a transitional slowing in the rate of growth of output and probably a temporary rise in the unemployment rate.

\section{Whil There Be a Resesions}

At present, there is no indication that a full-fledged recession is unavoidable. Real GNP did slow to a 2.4 percent rate of increase in the second quarter of 1973 , from an 8 percent increase in the preceding year. However, third quarter data are expected to show a rise in real product closer to its long-run potential rate of about 4 percent annually.

Despite a slight rise in the unemployment rate from 4.7 percent in July to 4.8 percent in August and September, there remains strong pressure on the productive capacity of the economy. The Federal Reserve's index of capacity utilization of major materials, the volume of help wanted ads, order backlogs, and the continued high level of retail sales all suggest substantial strength in the economy.

Such strength should carry on for some time. There are widespread reports of expansion in output being limited in many industries next year by shortages of raw materials and skilled labor. Thus, $I$ believe that a slowdown of output growth the balance of 1973 and early 1974 will be as much a reflection of supply constraints as a reduction in the growth of total demand.

The course of monetary expansion over the last half of 1973 and early 1974 could exercise such restraint on growth of total demand that a recession would be produced. For example, suppose there was a desire to curb inflation quickly by holding the money stock unchanged from mid-1973 until next summer. Our studies indicate that a recession would almost certainly occur next year if such a sharp and prolonged reduction in the rate of money growth should occur.

I believe there is a path available for making some progress toward the reduction in the average rate of inflation while avoiding a recession next year. Such a path would involve a modest deceleration in the rate of increase in the narrowly defined money stock for the last half of 1973 , followed by moderate growth in the first half of next year. Our studies suggest that such a course of persistent, moderate restraint on the rate of monetary expansion would foster less inflationary pressure in 1974 than we have had this year, while not being so restrictive as to plunge us into a sharp economic slowdown. If inflation is to be reduced eventually to a low rate, moderate money growth will have to be maintained for several years.

\section{Will There be a Credis Cnumb}

That is, will the flow of credit be sharply altered from its normal channels as in 1966 and in late 1969 and early 1970 ? In those years, the source of funds to financial institutions, such as savings and loan associations and mutual savings banks, was severely curtailed, as was the availability of mortgage money to home buyers. Market interest rates rose sharply because of a strong demand for credit in the face of a restricted growth in the supply. Legal ceilings on the interest rates payable by the savings institutions handicapped them in competing with market instru. ments for the savings of wealthy individuals and businesses. The "small" saver was unable to obtain the high yields available on market debt instruments. Consequently, the burden of monetary restraint was borne most heavily by financial intermediaries, the housing sector, and the small saver.

Whether another credit crunch will occur depends first on movements of market interest rates, and second, on the extent to which legal interest rate ceilings cause distortions in channels through which credit normally flows. The demand for credit, which is one of the factors influencing interest rates, should remain strong for some time. The quantity of credit demanded by both consumers and businesses has shown little sign of subsiding recently despite the current high level of interest rates. Surveys indicate business" men intended to continue to expand plant and equipment capacity through 1974. Although the cash position of many firms remains strong, it is expected that a sizeable volume of the funds necessary for expansion must be obtained in the credit markets.

On the other hand, credit demands of state and local governments have moderated with the advent of Federal revenue sharing. State and local governments were adversely affected during the past crunch periods because of the legal ceilings on the rates they could offer on bond issues, but revenue sharing has lessened state and local government vulnerability to any future crunch.

The Federal Government's budget, which had been in deficit (expenditures exceeding tax receipts) for thirteen consecutive quarters (on a national income accounts basis), was finally in balance in the second quarter of 1973 . Because of the strong pace of eco. nomic activity, which generated considerable tax revenues, and the exercise of fiscal restraint on expendi- 
tures, the Federal Government's demands for funds have moderated significantly. If the growth of aggregate demand in the economy slows, causing growth of tax revenues to slow, some step-up in Federal Gov. emment credit demands can be expected; however, I foresee no great pressures from Government deficits in the near future.

In short, growth of credit demands throughout the economy should continue strong, but at a moderated pace. Some further growth in demand for credit can be met without sharply higher intermediate and longterm interest rates. The movement of short-term market interest rates will depend on a great many factors including monetary actions.

Regardless of the monetary policy adopted, the likelihood of an availability crunch at recent levels of interest rates is less now than in the 1966 and 1969-70 periods. Legal cellings on interest rates paid by a number of savings institutions have been either eliminated or greatly relaxed in many cases. Moreover, expanding Federal or semi $\mathrm{F}$ ederal agencies such as FNMA and GNMA can be expected to supply more funds to the housing sector than in the earlier tight credit situations. Thus, the effects of monetary restraint, whenever applied, should be more evenly diffused throughout the economy.

\section{What is the Outhol for the Internutional Moneravy Stmution?}

In the past, painless solutions in this area have also been sought. So far they have escaped us. With the fixed international value of the dollar from 1944 to 1971 it was quite generally believed that the best of all possible worlds had been created. The risks of exchange rate movements were virtually eliminated, the dollar became the international currency and excesses of exports and imports were to be prevented through voluntary domestic adjustments or through internationally agreeable changes in the exchange rate.

Early in the post-war period, the United States supplied dollars to the world through the Marshall Plan and various grant arrangements, thus transferring resources to the war-ravaged parts of the world. This provided us with an export balance and pacified those who were worried about the balance of payments. Later, it provided dollars for international transactions, thus transferring resources back to the United States and providing export surpluses for other industrial nations.
But as other nations built up their industrial potential and began to compete and assert their sovereignty, economic and political realities began to emerge. The maintenance of the fixed dollar exchange rate, in the face of improving foreign productivity and sharply accelerating U.S. inflation, generated an overvalued dollar.

The result was an excess of U.S. imports and a deficit in the liquidity account with a hundred billion dollar accumulation of liquid assets by foreigners. There was also a realization that this accumulation of dollars meant a transfer of real resources from foreigners to the United States. Finally, there was the realization that the fixed international value of the dollar could no longer be maintained.

The floating exchange rate system, which emerged from the so-called crisis of 1971 , seems to be working reasonably well, even thongh it is subject to frequent interference from governmental agencies. The U.S. trade deficit has been virtually eliminated, global trade is again growing at pre-float rates, surplus countries can deal better with inflation, and all countries can pursue independent domestic economic policies.

But apparently everyone is not satisfied with this arrangement. The transition has not been without costs; our imports have become more expensive, countries who desire a permanent export balance cannot have it, and those who have a love affair with gold see it relegated simply to the status of any other commodity.

There are those who still believe that some governmental or international action can produce an arrangement quite similar to that which prevailed prior to mid-1971, and that such an arrangement would improve on the present situation. The recent meetings in Nairobi are a case in point. The participants of these meetings were groping for a more rigid exchange rate mechanism, while realizing that the old fixed rate system is unworkable. The basic argument that emerges is - how fixed should the rate be? The United States is arguing for an arrangement whereby the fixed rate must change when a country accumulates a certain amount of international veserves. Some other countries argue that a change should not take place automatically, but only atter consultation and agreement.

The U.S. position is quite similar to the floating rate mechanism, and the other position is almost identical to the old fixed rate arrangement. Again, some people have not learned the lessons of the past and, again, 
think that they can have all the benefits without having to pay the price.

If some fixity of exchange rates is at all desirable, then I would support the reported position of the U.S. Treasury. It is my firm belief that an international payments mechanism with a non-automatic change in the exchange rate would break down and bring about crises for which we would all have to pay.

\section{Summary Observarions}

The unhappiness of many people today would be greatly ameliorated if they thought inflation would be ended tomorrow. It simply cannot be done, given the stimulative fiscal and monetary actions of the past few years. Attempts to curb inflation quickly through controls have resulted in shortages, a reduction in economic freedom, and added uncertainty to everyone's life. Efforts by monetary and fiscal authorities to quickly end inflation would likely precipitate a credit crunch and a severe recession.
Adoption now of moderate stabilization actions would eventually reduce inflationary pressures with out a credit crunch or recession, but it would take considerable time, patience, and a minimum of legal interference in our market econony. Unfortunately, our past record on patience and avoiding the excesses of either stimulus or restraint is not one which inspires confidence.

Further, we seem to be developing a growing infatuation with the exercise of power to impede the operation of free markets by constantly surfacing new ideas and programs for controls which usually have ended up accomplishing exactly the opposite of what they were proposed to do. I am fully aware that there must be some minimum rules and regulations in a market-oriented democratic society, but why can't we keep our hands off the functioning of the markets and permit them to continue their proven, traditional role in the most efficient and equitable distribution of the product of our labors.

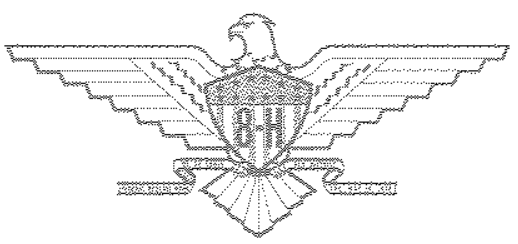

